\title{
Penentuan Tingkat Kerusakan Lahan pada Berbagai Bentuk Penggunaan Lahan di Daerah Gumelar, Kabupaten Banyumas Jawa Tengah
}

\author{
Prasmaji S1), Ruly Eko Kusuma'), Suwardi'1), dan F.G. Prihastuti1) \\ 1)Staf Pengajar Fakultas Pertanian Universitas Jenderal Soedirman \\ Jl. Prof. Dr. HR Boejamin 708 Purwokerto 53122
}

Korespondensi: sprasmaji@yahoo.com

\begin{abstract}
Land degradation represents a form of land productivity decrease that occurs due to the presence of incompatible land usage with land characteristic, which resulted in land capacity deterioration. Land degradation evaluation is determined based on Government Regulation No.150/2000 regarding land degradation control for biomass production, and Living Environment Minister Regulation No. 7/2006 for criteria standardization on soil measurement of biomass production. This research was conducted to evaluate land degradation levels based on physical characteristics of several land use patterns in Gumelar Region. The research used a survey method with homogenous land unit (HLU). HLU approaches were obtained from overlay between land use map and slope map. The measured parameters were i.e. solum thickness, surface rockiness, soil texture, bulk density, porosity and permeability. Results of the samples analysis were compared with the parameters values on Goverment Regulation No. 150/2000. The results of the research showed $69,7 \%$ of the total area of Gumelar had undergone land degradation. Garden land use contributed $51.5 \%$ land degradation, which was divided into several classes i.e. good and slight damage potential was $12.0 \%$, slightly damaged was $17.7 \%$, slightly damaged with damage potential was $4.8 \%$, and damaged was $17.1 \%$. Dry land contributed to damaged land degradation of $11.3 \%$, and categorized entirely as slightly damaged, while the shrub land use contributes $6.9 \%$ of degraded land (with $2.8 \%$ and $4.1 \%$ were good with slight damage potential and slightly damaged with damage potential, respectively). Largest contribution of land damage towards land degradation was dry land, all dry land in study area were in slightly damaged condition. Garden was the land use with lowest land degradation, which indicates the most suitable land use in the studied area was garden.
\end{abstract}

Keywords: land use, land degradation, homogenous land unit, overlay

\section{PENDAHULUAN}

Tekanan penggunaan lahan yang melebihi daya dukungnya terjadi akibat pertumbuhan jumlah penduduk yang sangat cepat, sehingga berdampak pada peningkatan kebutuhan hidup, dan semakin terbatasnya sumberdaya lahan yang tersedia. Pemanfaatan tanah untuk mencukupi kebutuhan hidup akan menyebabkan terjadinya konversi lahan dan penggunaan lahan secara terus menerus. Efek yang ditimbulkan adalah daya dukung lahan menjadi berkurang dan akan menyebabkan terjadinya kerusakan lahan.

Kerusakan lahan merupakan penurunan kapasitas lahan bagi produksi dan penurunan potensi bagi pengelolaan lingkungan atau disebut penurunan kualitas lahan. Karena adanya saling tindih ekosistem, selalu ada kerusakan atau perubahan pada sumberdayasumberdaya lain yang berasosiasi dengan sumberdaya yang dirujuk, misalnya penyusutan hutan menimbulkan penyusutan bahan organik tanah dan kerusakan sifat-sifat fisik tanah. Akibat kerusakan tanah tidak terbatas pada lahan setempat tetapi dapat menyebar ke daerah-daerah sekitarnya (Notohadinegoro, 1999).

Daerah penelitian terletak di wilayah Gumelar Kabupaten Banyumas. Daerah ini mempunyai topografi bergelombang dengan kemiringan lereng antara 0 sampai $<45 \%$. Penggunaan lahan di daerah ini meliputi sawah, pekarangan, tegalan atau kebun, kolam, hutan negara, perkebunan negara dan penggunaan lain. Penggunaan lahan yang paling luas adalah tegalan atau kebun, sebesar 
4.269,23 ha. Kecuraman lereng yang cukup besar di wilayah studi merupakan salah satu faktor yang menyebabkan terjadinya kerusakan lahan.

Berdasarkan Peraturan Pemerintah No. 150 tahun 2000 tentang Pengendalian Kerusakan Tanah untuk Produksi Biomassa, dapat diketahui bahwa Pengendalian Kerusakan Tanah untuk Produksi Biomassa merupakan upaya untuk mempertahankan kondisi tanah melalui cara-cara yang tidak memberi peluang berlangsungnya proses kerusakan tanah. Satuan tanah untuk penetapan status kerusakan tanah ditetapkan berdasarkan hasil analisis inventarisasi kondisi iklim, topografi, potensi sumber kerusakan dan penggunaan tanahnya. Penetapan kondisi tanah tersebut dilakukan terhadap areal tanah yang berpotensi mengalami kerusakan tanah.

Peraturan Pemerintah No. 150 Tahun 2000 juga digunakan sebagi acuan penentuan tingkat kerusakan lahan. Kriteria yang digunakan dalam penentuan tingkat kerusakan lahan tersebut didasarkan pada sifat dasar tanah. Sifat dasar tanah ini mencakup sifat fisika, kimia dan biologi. Sifat ini merupakan penentu kemampuan tanah dalam menyediakan air dan unsur hara yang cukup bagi kehidupan tumbuhan.

Berpedoman pada PP tersebut, maka dilakukan penelitian untuk menentukan tingkat kerusakan lahan pada berbagai pola penggunaan lahan di wilayah Gumelar Kabupaten Banyumas. Pemilihan lokasi penelitian ini didasarkan pada pertimbangan kelerengan yang bervariasi dan tingginya curah hujan. Kedua faktor tersebut dinilai sebagai faktor dominan dalam penentuan tingkat kerusakan tanah.

\section{BAHAN DAN METODE}

\subsection{Bahan dan Alat Penelitian}

Bahan yang digunakan yaitu bahan-bahan kimia, peta kemiringan lereng, peta jenis tanah, peta penggunaan dan peta rupa bumi wilayah penelitian. Alat yang digunakan adalah seperangkat alat survei (bor tanah, cangkul, kompas geologi, pisau lapang) dan peralatan laboratorium seperti: gelas ukur, erlenmeyer, pipet, labu takar, kertas saring, labu Kjeldahl.

\subsection{Metodologi}

Metode yang digunakan adalah metode survei tanah dengan pendekatan satuan lahan homogen (SLH). SLH ditentukan atas dasar tumpang susun antara peta jenis tanah, penggunaan lahan dan peta kemiringan lereng. Selanjutnya dilakukan pengamatan lapang dan pengambilan sampel tanah, hasil analisis dievaluasi dengan program PSSL.

Berdasarkan PP No. 150 tahun 2000 dan Permen KNLH No. 7 tahun 2006, terdapat 6 parameter yang harus diukur untuk menentukan kerusakan tanah berdasarkan sifat fisiknya pada berbagai bentuk penggunaan lahan, yaitu : ketebalan solum, batuan permukaan, komposisi fraksi, berat jenis isi, porositas total dan permeabilitas. Metode pengukuran yang digunakan dapat dijelaskan sebagai berikut:

a. Pengukuran ketebalan tanah dilakukan secara langsung pada profil tanah dengan menggunakan meteran, mulai dari permukaan tanah sampai ke lapisan pembatas sistem perakaran

b. Batuan permukaan diukur secara langsung di lapang dengan membuat areal percontohan $2 \times 2 \mathrm{~m}$

c. Komposisi fraksi diukur secara gravimetrik

d. Pengukuran berat jenis isi dilakukan dengan metode gravimetrik

e. Porositas total dihitung dari nilai berat isi dan berat jenis partikel

f. Permeabilitas dengan metode gravimetrik

Data dianalisis dengan metode pembanding dan parsial. Setelah proses pengambilan sampel tanah selesai, dilakukan 
analisis di laboratorium. Hasil analisis dibandingkan dengan kriteria baku kerusakan tanah baik di lahan kering maupun di lahan basah berdasarkan PP No. 150 tahun 2000 tentang pengendalian kerusakan tanah untuk produksi biomassa. Jika salah satu hasil analisisnya melampaui nilai ambang kritis, maka tanah tersebut dapat dikatakan rusak

\section{HASIL DAN PEMBAHASAN}

\subsection{Kondisi Umum Wilayah Penelitian}

Wilayah Gumelar terletak antara $108^{0}$ 57'56" - $109^{0} 01^{\prime} 17^{\prime \prime}$ BT, dan $07^{0} 21^{\prime} 45^{\prime \prime}-07^{0}$ 26' 19" LS, dengan luas wilayah 9394,86 ha. Menurut Oldeman termasuk tipe iklim B, topografinya berombak sampai bergunung dengan kemiringan antara 3 - > 40\%. Wilayah studi memiliki jenis tanah kompleks latosol merah kekuningan dan podsolik merah kuning.

Penggunan lahan di wilayah Gumelar yang paling luas digunakan untuk tegalan atau kebun, yaitu sebesar 4269,79 Ha, sawah beririgasi $1092,12 \mathrm{Ha}$; pekarangan 777,79 Ha; kolam 4,28 Ha; hutan negara 2544,06 Ha; perkebunan $579 \mathrm{Ha}$; dan untuk penggunaan lain sebesar 126,70 Ha.

\subsection{Klasifikasi tingkat kerusakan lahan}

Klasifikasi kerusakan tanah mengacu pada Peraturan Pemerintah No. 150 Tahun 2000.
Penilaian tingkat kerusakan tanah dimulai dengan penilaian potensi kerusakan tanah. Tabel 1 menyajikan hasil penilaian kerusakan tanah berdasarkan deliniasi penggunaan lahan. Analisis potensi kerusakan tanah dilakukan melalui program pusat studi sumberdaya lahan.

Tabel 1 Potensi tingkat kerusakan lahan berdasarkan pemrogaman PSSL

\begin{tabular}{lcccc}
\hline \multirow{2}{*}{\begin{tabular}{c} 
Lahggunaan \\
\cline { 2 - 5 }
\end{tabular}} & $8-15 \%$ & $15-25 \%$ & $25-40 \%$ & $>40 \%$ \\
\hline Kebun & $\mathrm{B}$ & $\mathrm{AR}$ & $\mathrm{B}$ & $\mathrm{AR}$ \\
Semak & - & - & $\mathrm{AR}$ & $\mathrm{B}$ \\
Ladang & - & $\mathrm{R}$ & $\mathrm{B}$ & $\mathrm{B}$ \\
\hline Keterangan: & & & &
\end{tabular}

$\mathrm{B}=$ Baik; $\quad \mathrm{AR}=$ Agak Rusak; $\quad \mathrm{R}=$ Rusak

Penentuan tingkat kerusakan dilakukan setelah pengambilan sampel tanah dan analisis laboratorium. Berdasarkan hasil analisis laboratoriuam serta kriteria kerusakan lahan PP No. 150 tahun 2000, diperoleh 5 (lima) tipe kerusakan antara lain baik (B), baik berpotensi agak rusak (BPAR), agak rusak (AR), agak rusak berpotensi rusak (ARBR) dan rusak (R). Hasil analisis menunjukkan bahwa setiap SLH mempunyai penyebab kerusakan yang berbeda, sehingga penanganannya juga berbeda. Hasil verifikasi dan skoring berdasarkan PP disajikan pada Tabel 2. Sebaran masing-masing tipe kerusakan lahan dapat dilihat pada Gambar 1.

Tabel 2 Hasil verifikasi dan skoring berdasarkan PP No 150 tahun 2000

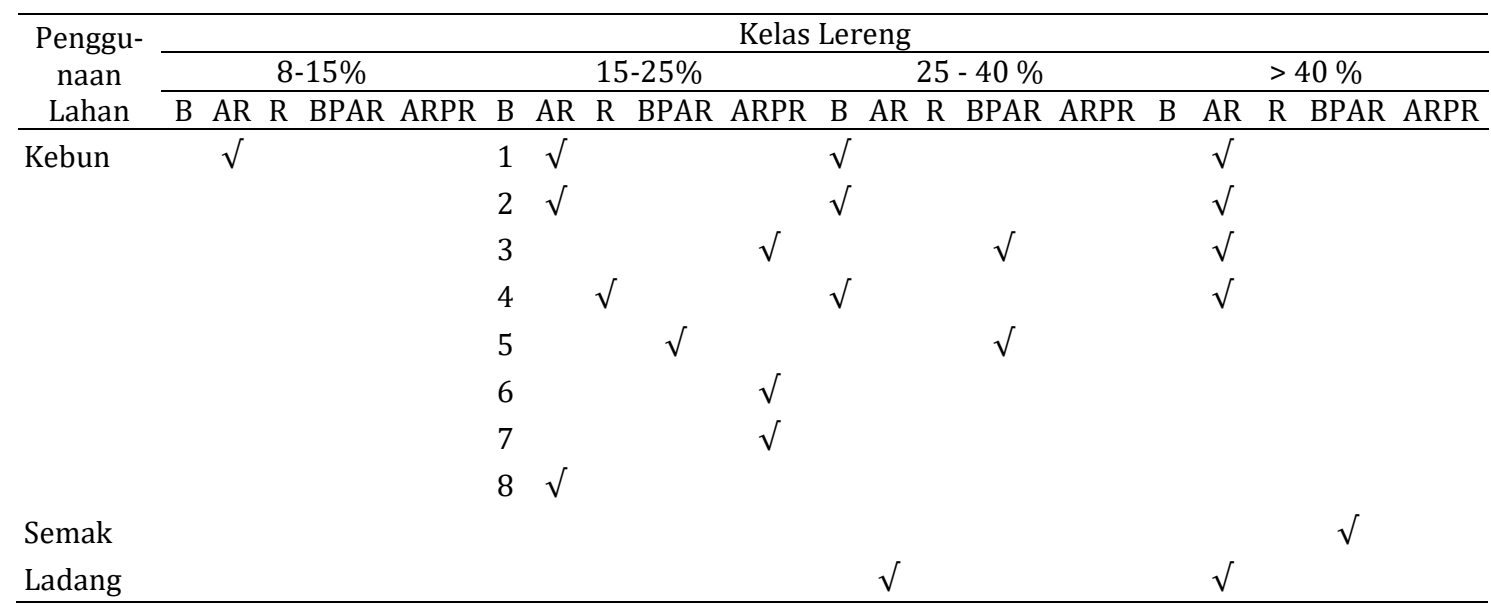




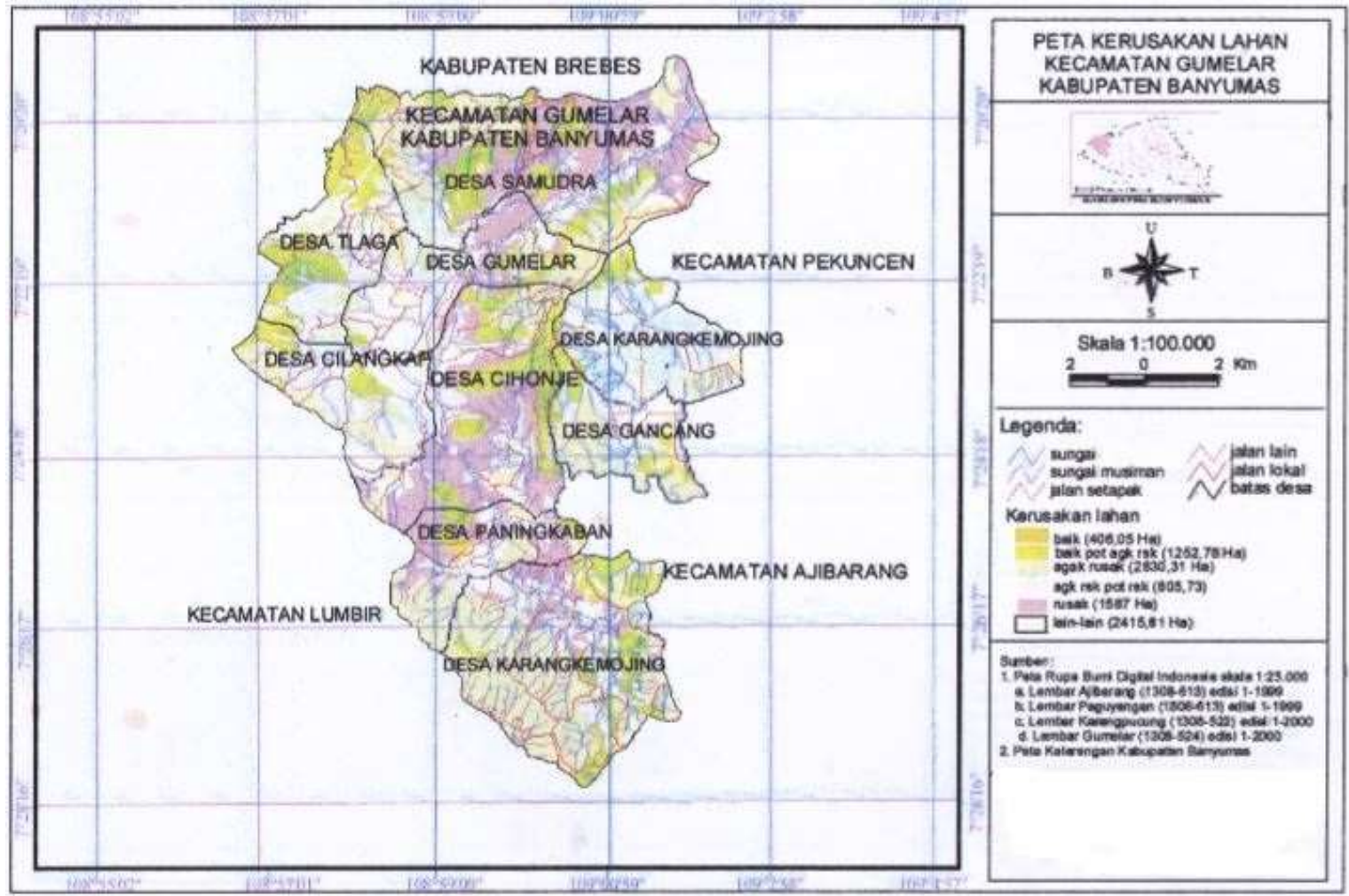

Gambar 1 Peta Kerusakan Lahan Di Wilayah Gumelar

\subsection{Pengaruh Penggunaan Lahan terhadap Kerusakan Lahan}

Penggunaan lahan yang digunakan dalam penelitian ini adalah kebun, semak dan ladang. Masing-masing penggunaan lahan tersebut mempunyai konstribusi dalam menentukan rusak atau tidaknya suatu lahan (Kartasapoetra dkk., 1991).

\subsubsection{Kebun}

Kebun merupakan penggunaan lahan terluas di daerah studi, yaitu 5194,2 ha atau $51,5 \%$ dari luas wilayah studi. Kerusakan pada lahan kebun mempunyai tingkat yang berbeda-beda, mulai dari baik sampai rusak. Luas tingkat kerusakan lahan kebun dapat pada Tabel 3.

Berdasarkan Tabel 3, diketahui bahwa 406,0 ha atau 7,8\% dari luas lahan di daerah studi mempunyai kondisi baik (B), kondisi lahan yang baik berpotensi agak rusak (BPAR) seluas 1115,3 ha $(21,5 \%)$. Agak rusak merupakan kondisi lahan yang paling luas yaitu 1641,8 ha $(31,6 \%)$. Lahan dengan kondisi agak rusak berpotensi rusak (ARPR) seluas 443,8 ha $(8,5)$, sisanya merupakan kondisi lahan rusak (R) seluas 1587,3 $(30,6 \%)$.

Tabel 3 Luas kerusakan pada lahan kebun

\begin{tabular}{lcc}
\hline \multicolumn{1}{c}{$\begin{array}{c}\text { Kondisi } \\
\text { Lahan }\end{array}$} & Luas (ha) & Presentase \\
\hline B & 406,0 & 7,8 \\
BPSR & 1115,3 & 21,5 \\
AR & 1641,8 & 31,6 \\
ARPR & 443,8 & 8,5 \\
R & 1587,3 & 30,6 \\
\hline Jumlah & $\mathbf{5 1 9 4 , 2}$ & $\mathbf{1 0 0}$ \\
\hline Keterangan: & B=baik; BPAR=baik berpotensi agak \\
& rusak; AR= agak rusak; ARPR=agak \\
& berpotensi agak rusak; R=rusak.
\end{tabular}

\subsubsection{Ladang}

Luas ladang sekitar 1050,3 ha atau 11,3\% dari luas wilayah studi. Berdasarkan hasil verifikasi PP No 150 Tahun 2000, seluruh ladang termasuk dalam kondisi agak rusak. 
Kerusakan lahan yang terjadi diduga karena tidak semua permukaan tanahnya tertutup vegetasi yang dapat menghalangi jatuhnya air hujan ke tanah secara langsung akibatnya butir-butir tanah pecah dan pori tanah tertutup. Berkurangnya pori tanah tersebut berpengaruh pada nilai porositas dan permeabilitas tanahnya. Semakin rendah nilai porositas tanah, maka semakin rendah pula kemampuan tanah untuk mengikat dan menyimpan air serta kemampuan untuk merembeskan air juga berkurang (Suripin, 2001).

Selain itu, pada tanah ladang terjadi pengolahan tanah yang terlalu intensif sehingga terjadi perubahan struktur tanah dan mempengaruhi jumlah pori-pori tanah yang ada, akibatnya tanah menjadi lebih padat. Pengolahan tanah justru menurunkan ruang pori, lebih rendah dari tanah yang tidak pernah diolah (Soepardi, 1983; Hardjowigeno, 2003).

\subsubsection{Semak}

Lahan semak seluas 637,7 ha atau 6,9\% dari luas wilayah studi. Tingkat kerusakanya yaitu baik berpotensi agak rusak, agak rusak dan agak rusak berpotensi rusak (Tabel 4).

Tabel 4 Luas kerusakan lahan semak

\begin{tabular}{lcc}
\hline Kondisi Lahan & $\begin{array}{c}\text { Luas } \\
\text { (ha) }\end{array}$ & $\begin{array}{c}\text { Presentase } \\
(\%)\end{array}$ \\
\hline BPAR & 275,8 & 43,2 \\
ARPR & 361,9 & 56,8 \\
\hline Jumlah & $\mathbf{6 3 7 , 7}$ & $\mathbf{1 0 0}$ \\
\hline Keterangan: & $\begin{array}{l}\text { BPAR= } \\
\text { ARPR= agak rusak berpotensi rusak }\end{array}$
\end{tabular}

Berdasarkan Tabel 4 kerusakan lahan semak paling luas yaitu agak rusak potensi rusak (ARPR) seluas 361,9 ha atau 56,8\% dari luas semak. Kerusakan lahan semak diduga karena lahan tersebut hanya terdapat tanaman rendah dengan perakaran sedikit, sehingga kurang optimal menyerap air. Hal tersebut menyebabkan semakin besarnya aliran permukaan.

Tingkat kerusakan lahan di daerah studi sudah cukup luas, sekitar 69,7\% dari luas wilayah. Kerusakan lahannya mulai dari baik sampai rusak, seperti yang tertera pada Tabel 5.

Tabel 5 Luas tingkat kerusakan lahan berdasarkan PP No 150 Tahun 2000 di daerah studi

\begin{tabular}{lcc}
\hline $\begin{array}{c}\text { Tingkat } \\
\text { Kerusakan }\end{array}$ & Luas (ha) & $\begin{array}{c}\text { Presentase } \\
\text { (\%) }\end{array}$ \\
\hline B & 406,0 & 4,3 \\
BPAR & 1252,8 & 13,5 \\
AR & 2830,3 & 30,4 \\
ARBR & 805,7 & 8,7 \\
R & 1587,3 & 17,1 \\
Lain-lain & 2415,8 & 26,0 \\
\hline Jumlah & $\mathbf{9 2 9 7 , 9}$ & $\mathbf{1 0 0}$ \\
\hline Keterangan: & B=baik; BPAR=baik berpotensi agak \\
& rusak; AR= agak rusak; ARPR=agak \\
& berpotensi agak rusak; R=rusak
\end{tabular}

Berdasarkan Tabel 5 dapat diketahui tingkat kerusakan lahan yang terbesar yaitu agak rusak, seluas 2830,3 ha atau 30,4\%, sedangkan lahan yang baik (tidak rusak) seluas 406,0 ha atau $4,3 \%$, sehingga dapat disimpulan bahwa lahan yang rusak seluas 64,76 ha atau $69,7 \%$ dari luas wilayah studi.

Setiap penggunaan lahan memiliki kontribusi berbeda terhadap terjadinya kerusakan lahan (Kartasapoetra, 1991; Arsyad, 2010). Ditribusi kerusakan lahan pada setiap penggunaan lahan, disajikan pada Tabel 6. Penggunaan lahan yang memiliki kontribusi paling besar terhadap kerusakan lahan yaitu ladang, dikarenakan seluruh ladang di daerah studi termasuk kondisi agak rusak. Penggunaan lahan yang memiliki kontribusi paling kecil adalah kebun, sehingga dapat diambil kesimpulan bahwa penggunaan lahan yang perlu dikembangkan di daerah studi adalah kebun. 
Tabel 6 Distribusi kerusakan daerah studi

\begin{tabular}{lcccccccccccc}
\hline $\begin{array}{c}\text { Penggu- } \\
\text { naan } \\
\text { Lahan }\end{array}$ & \multicolumn{3}{c}{ B } & \multicolumn{4}{c}{ BPAR } & \multicolumn{2}{c}{ AR } & \multicolumn{2}{c}{ ARPR } & \multicolumn{2}{c}{ R } & \multicolumn{2}{c}{ Luas Total } \\
\cline { 2 - 14 } & Ha & $\%$ & Ha & $\%$ & Ha & $\%$ & Ha & $\%$ & Ha & $\%$ & Ha & $\%$ \\
\hline Kebun & 406,05 & 4,36 & $1.115,28$ & 11,99 & $1.641,75$ & 17,66 & 443,82 & 4,78 & $1.587,30$ & 17,07 & $5.194,18$ & 55,86 \\
Semak & - & - & - & - & - & - & 361,90 & 3,89 & - & - & 637,66 & 6,86 \\
Ladang & - & - & - & - & $1.050,29$ & 11,30 & - & - & - & - & $1.050,29$ & 11,30 \\
Lain-lain & - & - & - & - & - & - & - & - & - & - & $2.415,81$ & 25,98 \\
\hline
\end{tabular}

Keterangan: $\mathrm{B}=$ baik; $\mathrm{BPAR}=$ baik berpotensi agak rusak; $\mathrm{AR}=$ agak rusak; ARPR=agak berpotensi agak rusak; $\mathrm{R}=$ rusak

\section{KESIMPULAN}

Kerusakan lahan di wilayah Gumelar sekitar 69,65\%. Tingkat kerusakan yang paling luas adalah lahan agak rusak sebesar 2830,31 ha atau $30,44 \%$, dan yang paling kecil adalah agak rusak berpotensi rusak sebesar 805,73 ha atau $8,67 \%$.

Penggunaan lahan kebun memiliki konstribusi yang paling luas yaitu 51,50\% tetapi mempunyai tingkat kerusakan paling kecil, yaitu baik potensi agak rusak 12,0\%, agak rusak $17,7 \%$, agak rusak potensi rusak $4,8 \%$ dan rusak $17,0 \%$. Ladang seluas $11,3 \%$ semua termasuk pada kondisi lahan agak rusak. Semak memiliki kerusakan sebesr $6,9 \%$, sekitar $2,8 \%$ termasuk baik potensi agak rusak, dan 3,9\% termasuk dalam kondisi lahan agak rusak potensi rusak.

\section{DAFTAR PUSTAKA}

Arsyad, S. 2010. Konservasi Tanah dan Air. IPB, Press Bogor

Hardjowigeno, S. 2010. Ilmu Tanah. Akamedika Pressindo, Jakarta.

Kartasapoetra, A.G. Kartasapoetra, dan M.M. Sutedjo. 1991. Teknologi Konservasi Tanah dan Air. Rineka Cipta. Jakarta.

Notohadinegoro, T. 1999. Diagnosis Sifat Fisik, Kimia dan Hayati Kerusakan Lahan. Fakultas Pertanian UGM, Yogyakarta.
Peraturan Pemerintah No. 150 Tahun 2000 tentang Pengendalian Kerusakan Tanah untuk Produksi Biomassa (Lampiran PP No.150 tanggal 23 Des Th 2000. Sekretaris Negara Republik Indonesia, Jakarta

Soepardi, G. 1983. Sifat dan Ciri Tanah. Pustaka Buana. Jakarta.

Suripin. 2001. Pelestarian Sumberdaya Tanah dan Air. Penerbit Andi. Yogyakarta. 